\title{
In vitro cultivation of primary intestinal cells from Eisenia fetida as basis for ecotoxicological studies
}

\author{
Simon A. B. Riedl $\mathbb{1}^{1} \cdot$ Matthias Völkl $\mathbb{D}^{1} \cdot$ Anja Holzinger $\mathbb{B}^{2} \cdot$ Julia Jasinski $\mathbb{D}^{3} \cdot$ Valérie Jérôme $\mathbb{C}^{1} \cdot$ \\ Thomas Scheibel $\mathbb{1}^{3} \cdot$ Heike Feldhaar $\mathbb{1}^{2} \cdot$ Ruth Freitag $\mathbb{B}^{1}$
}

Accepted: 13 October 2021 / Published online: 17 November 2021

(c) The Author(s) 2021

\begin{abstract}
The earthworm Eisenia fetida is a commonly used model organism for unspecific soil feeders in ecotoxicological studies. Its intestinal cells are the first to encounter possible pollutants co-ingested by the earthworm, which makes them prime candidates for studies of toxic effects of environmental pollutants on the cellular as compared to the organismic level. In this context, the aim of this study was to demonstrate the suitability of preparations of primary intestinal $E$. fetida cells for in vitro ecotoxicological studies. For this purpose, a suitable isolation and cultivation protocol was established. Cells were isolated directly from the intestine, maintaining $>85 \%$ viability during subsequent cultivations (up to $144 \mathrm{~h}$ ). Exposure to established pollutants and soil elutriates comprising silver nanoparticles and metal ions $\left(\mathrm{Cu}^{2+}, \mathrm{Cd}^{2+}\right)$ induced a significant decrease in the metabolic activity of the cells. In case of microplastic particles (MP particles), namely 0.2, 0.5, 2.0, and $3.0 \mu \mathrm{m}$ diameter polystyrene (PS) beads as well as 0.5 and $2.0 \mu \mathrm{m}$ diameter polylactic acid (PLA) beads, no active uptake was observed. Slight positive as well as negative dose and size dependent effects on the metabolism were seen, which to some extent might correlate with effects on the organismic level.
\end{abstract}

Keywords Earthworm $\cdot$ Eisenia fetida $\cdot$ Environmental pollutants $\cdot$ Microplastic $\cdot$ Cytotoxicity $\cdot$ Primary cells

\section{Introduction}

The earthworm Eisenia fetida is a commonly used terrestrial model organism in ecotoxicological research. As soil feeders, earthworms like E. fetida unselectively ingest soil and therefore also any environmental pollutant included therein. Consequently, their intestinal tissue is directly exposed to these foreign materials, and it is commonly assumed that effects of common pollutants

These authors contributed equally: Simon A. B. Riedl, Matthias Völkl

Supplementary information The online version contains supplementary material available at https://doi.org/10.1007/s10646021-02495-2.

Ruth Freitag

ruth.freitag@uni-bayreuth.de

1 Process Biotechnology, University of Bayreuth, 95440 Bayreuth, Germany

2 Animal Ecology I, Bayreuth Center of Ecology and Environmental Research (BayCEER), University of Bayreuth, 95440 Bayreuth, Germany

3 Biomaterials, University of Bayreuth, 95440 Bayreuth, Germany such as metal ions (Nahmani et al. 2007; Sivakumar 2015) or nanomaterials (Garcia-Velasco et al. 2016; Kwak et al. 2014) on the organismic level such as mortality, reduced growth rate and reproduction, are mediated by damage to the gut cells and tissues. However, organismic reactions are complex, and understanding effects mechanistically can be challenging. An important aspect of deconvolving the overall effects is the identification of the response on the cellular level using cell lines or primary cells (Revel et al. 2021). Primary cells isolated from a specific tissue initially possess characteristics comparable to those of the cells in vivo and reflect their physiological state and reactions. This enables studies of effects on the cellular level, which are more representative for the in vivo situation than experiments with established cell lines. Moreover, such studies are also possible in case of organisms and tissues, for which no established cell lines exist.

In case of E. fetida, no cell lines or standard procedures for the isolation and cultivation of primary intestinal cells are currently available. Protocols do exist for the isolation and cultivation of various earthworm coelomocytes, i.e., the phagocytic leukocytes in the coelom which are the established primary cell type for 
ecotoxicological or immune response studies (Diogène et al. 1997; Eyambe et al. 1991; Fuller-Espie et al. 2015; Garcia-Velasco et al. 2019; Stein and Cooper 1981; Toupin et al. 1977). The respective culture media are mostly based on L-15 medium with various supplements and adjusted osmolalities (Bilej et al. 1990; Irizar et al. 2014; Roch et al. 1975; Toupin et al. 1977). However, these macrophage-like cells are physiologically and functionally different from intestinal cells and the direct compatibility of protocols for their isolation and cultivation with the needs of the intestinal cells is unlikely. In case of primary intestinal cells from the earthworm Pheretima aspergillum, Schneider's Drosophila Medium (SDM) was shown to support proliferation (Gong et al. 2014), while Hansen S-301, a formulation based on SDM, has previously been used to keep tissue fragments of E. fetida in culture (Battaglia and Davoli 1997).

In recent years, pollution of the environment with microplastic (MP) became a matter of global concern. MP is defined as any plastic piece between 1 and $5000 \mu \mathrm{m}$ in size. Soils in particular have been reported to represent MP sinks (Büks and Kaupenjohann 2020; He et al. 2020; Piehl et al. 2018). MP can enter terrestrial habitats via various pathways, including natural precipitation (rain, snow), illegal waste deposition, sewage sludge and wastewater, agricultural practices (plastic foil for mulching), or in some cases even organic fertilizer (Chae and An 2018; Weithmann et al. 2018). Several studies have already reported direct or indirect negative effects of MP on earthworms. For Eisenia andrei, histopathological evidence for gut tissue damage and responses of the immune system after exposure to polyethylene MP particles was shown (Rodriguez-Seijo et al. 2017). In E. fetida, MP exposure led to an increase in the organisms' oxidative stress levels (Chen et al. 2020; Rodríguez-Seijo et al. 2018; Wang et al. 2019). However, aside from the obvious tissue damage, the putative influence of MP particles on the intestinal cells has neither been demonstrated nor excluded. This knowledge would be important for a better mechanistic understanding of how MP affects the cellular as well as the organismic level.

The aim of the study was to prove the suitability of using intestinal primary cells of $E$. fetida earthworms for ecotoxicology studies using Ag nanoparticles and metal ions $\left(\mathrm{Cu}^{2+}\right.$, $\mathrm{Cd}^{2+}$ ) examples. Our protocol effectively yielded primary cells of high viability during short-time cultivation. Cytotoxic effects were determined using an adapted assay for metabolic activity. Subsequently, the effect of polystyrene (PS), as representative of commodity polymers, as well as polylactic acid (PLA), as an example for biodegradable polymers, MP particles on the metabolic activity of the cells was determined as well as their putative cellular uptake.

\section{Materials and methods}

\section{Materials}

Cell culture materials were obtained from Greiner Bio-One International $\mathrm{GmbH}$ (Frickenhausen, Germany). If not otherwise indicated, cell culture solutions and supplements (L-glutamine, HEPES ((4-(2-hydroxyethyl)-1-piperazineethanesulfonic acid), penicillin, streptomycin, amphotericin B) and DPBS (Dulbecco's Phosphate Buffered Saline) were obtained from Biochrom AG (Berlin, Germany). L-15 medium was purchased from Lonza Group AG (Visp, Switzerland) and Schneider's Drosophila Medium (SDM) from Fisher Scientific GmbH (Schwerte, Germany). Sigma Aldrich (Taufkirchen, Germany) was used the supplier for chemicals such as galactose, lactalbumin hydrolysate, tetracycline, cell culture grade water (for medium preparation) and FCS (Fetal Calf Serum). Gentamycin was obtained from Biowest (Nuaillé, France). Ultrapure water for buffer preparation was produced by a Millipore unit (Synergy Water Purification System, Merck KGaA, Darmstadt, Germany). Collagenase type II from Clostridium histolyticum (CLS II, \#C2-28, Lot Number 47N17872A, $280 \mathrm{U} / \mathrm{mg}$ ) was purchased from Biochrom AG. MTT (3(4,5-dimethylthiazol-2-yl)-2,5-diphenyltetrazolium bromide) reagent was received from Alfa Aesar (Ward Hill, Massachusetts, USA).

Sterile filters $(0.2 \mu \mathrm{m}$ cellulose acetate $)$ were purchased from VWR International (Darmstadt, Germany) and cell strainers from pluriSelect Life Science (Leipzig, Germany).

\section{Silver nanoparticles, metal ions, and microplastic particles}

Silver nanoparticles with a size of $40 \mathrm{~nm}$ were obtained from Alfa Aesar (Ward Hill, Massachusetts, USA) and supplied at a concentration of $20 \mu \mathrm{g} / \mathrm{mL}$ and an absorption maximum at $416 \mathrm{~nm}$ in $2 \mathrm{mM}$ sodium citrate buffer (\#J67090). The Eppendorf Concentrator 5301 (Eppendorf AG, Hamburg, Germany) was used to prepare a more concentrated stock solution at $45{ }^{\circ} \mathrm{C}$ for $60 \mathrm{~min}(65 \mu \mathrm{g} / \mathrm{mL}$ in $6.5 \mathrm{mM}$ sodium citrate) for use in the viability assays, see below. $\mathrm{CuCl}_{2}$ and $\mathrm{CdCl}_{2}$ were dissolved at a concentration of $100 \mathrm{mg} / \mathrm{mL}$ in cell culture grade water and the solution was sterilized by filtration $(0.2 \mu \mathrm{m}$ cellulose acetate) . Polystyrene (PS) MP particles were obtained from Polysciences Inc. (Warrington, Pennsylvania, USA) with fluorescence (yellow green, excitation $441 \mathrm{~nm}$, emission $486 \mathrm{~nm}$ ) and without and with average sizes of $0.2 \mu \mathrm{m}$ (\#07304-15 and \#17151-10), 0.5 $\mu \mathrm{m}$ (\#07307-15 and $\# 17152-10), 2.0 \mu \mathrm{m}$ (\#19814-15 and \#18338-5), and $3.0 \mu \mathrm{m}$ (\#17134-15 and \#17155-2). Polylactic acid (PLA) MP particles were obtained from Micromod Partikeltechnologie 
GmbH (Rostock, Germany), with fluorescence (green, excitation $502 \mathrm{~nm}$, emission $527 \mathrm{~nm}$ ) and without and with average sizes of $0.5 \mu \mathrm{m}$ (\#11-00-502 and \#51-00-502) and $2.0 \mu \mathrm{m}$ (\#11-00-203 and \#51-00-203). All MP particles were delivered as aqueous suspension at a concentration of $2.5 \%(\mathrm{w} / \mathrm{v})$ for the PS particles and of $1.0 \%(\mathrm{w} / \mathrm{v})$ for the PLA particles. The particles were declared as "plain" without surface modification, but, according to the manufacturer, they had a slightly negative surface charge due to residual sulphate ester groups.

\section{Buffers}

M-HBSS (Modified Hanks Balanced Salt Solution) without GGE (Guaiacol Glyceryl Ether) (pH 7.25, 210 mOsmol/kg) was prepared in house according to a previously published protocol (Diogène et al. 1997) replacing GGE by $\mathrm{NaCl}$ to assure a constant osmolality. When indicated, GGE was supplemented to the buffer at a final concentration of $50.4 \mathrm{mM}$ using a concentrated stock solution $(500 \mathrm{mM})$.

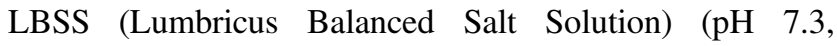
$171 \mathrm{mOsmol} / \mathrm{kg}$ ) was prepared in house as previously published (Stein and Cooper 1981). Both buffers were sterilized by filtration $(0.2 \mu \mathrm{m}$ cellulose acetate). The detailed composition of both buffers is given in Table S1.

\section{Handling and rearing of Eisenia fetida}

E. fetida were kept as synchronized laboratorial cultures under controlled conditions (temperature constant $15^{\circ} \mathrm{C}$, $70 \%$ moisture, photoperiod $16 \mathrm{~h}$ light, $8 \mathrm{~h}$ darkness) in worm composters filled with dampened soil mixed with sphagnum peat. Every week the cultures were fed with oatmeal and wormfood (Superwurm e.K., Düren, Germany).

\section{Production of cell-free worm filtrate (WF)}

A cell-free worm filtrate (WF) of E. fetida for media supplementation was produced in house as follows. About 30 mature worms were washed to remove external soil and transferred into a sterile culture dish covered with moistened filter paper to naturally void their intestine. After $24 \mathrm{~h}$, the worms were pooled and the wet weight was determined. For anaesthesia the worms were incubated at $-20^{\circ} \mathrm{C}$ for $10 \mathrm{~min}$. $50 \mathrm{~mL}$ M-HBSS was added to $10 \mathrm{~g}$ of earthworms and the mix was homogenized in a hand blender. The homogenate was pressed through a $70 \mu \mathrm{m}$ cell strainer with the help of a syringe piston collecting the flow through on ice. To remove any remaining tissue and solids, the filtrate was centrifuged $\left(3990 \times g, 2.5 \mathrm{~h}, 4{ }^{\circ} \mathrm{C}\right)$ and the supernatant aliquoted in $2 \mathrm{~mL}$ reaction tubes to be stored at $-20{ }^{\circ} \mathrm{C}$.

\section{Preparation and isolation of the intestinal tracts from Eisenia fetida}

Mature earthworms intended for the isolation of primary intestinal cells were transferred into a sterile culture dish covered with moistened filter paper $24 \mathrm{~h}$ before the procedure to naturally void their intestine. To prevent bacterial and fungal growth, M-HBSS was supplemented with $100 \mathrm{U} / \mathrm{mL}$ penicillin, $100 \mu \mathrm{g} / \mathrm{mL}$ streptomycin, $60 \mu \mathrm{g} / \mathrm{mL}$ tetracycline, $50 \mu \mathrm{g} / \mathrm{mL}$ gentamycin and $2.5 \mu \mathrm{g} / \mathrm{mL}$ amphotericin B ("PSTGA"), prior to the dissection of the worms. Worms were anaesthetized by incubation at $-20^{\circ} \mathrm{C}$ for $10 \mathrm{~min}$ and decapitated. Then, the animal's gut was dissected in pre-cooled $\left(4^{\circ} \mathrm{C}\right)$ M-HBSS supplemented with PSTGA, taking care to obtain a highly intact intestine, while avoiding contamination from undesired parts of surrounding tissue. However, due to the tight connection of the intestine, e.g., with chloragogen tissue, a cross contamination of the intestinal tissue with parts of other tissue cannot be completely excluded. The isolated intestine was transferred into fresh, pre-cooled M-HBSS/PSTGA and cleaned of any remaining gut content. The cleaned gut tissue was then transferred into $0.5 \mathrm{~mL}$ fresh M-HBSS/PSTGA precooled to $4{ }^{\circ} \mathrm{C}$. The wet weight was determined (ranging between 23 and $162 \mathrm{mg}$ per worm) and the tissue stored on ice until cell isolation.

\section{Isolation of primary intestinal cells from Eisenia fetida}

To facilitate the isolation, the gut tissue was digested using collagenase II $\left(90 \mathrm{~min}, 37^{\circ} \mathrm{C}\right.$ in $500 \mu \mathrm{L}$ M-HBSS/PSTGA and $10 \mu \mathrm{g} / \mathrm{mL}$ collagenase II, under continuous agitation $(500 \mathrm{rpm})$ in an Eppendorf Thermomixer F1.5). After $90 \mathrm{~min}$, the liquid suspension containing the released cells was transferred into a fresh $1.5 \mathrm{~mL}$ reaction tube and centrifuged at $200 \times g$ for $5 \mathrm{~min}$. The supernatant was removed, the cells were resuspended in $1 \mathrm{~mL}$ M-HBSS/PSTGA and filtered through a $20 \mu \mathrm{m}$ cell strainer. The cells were again pelleted by centrifugation $(200 \times g$ for $5 \mathrm{~min})$ and resuspended in $100 \mu \mathrm{L}$ M-HBSS/PSTGA to inoculate the wells of the cell culture plates.

\section{Cultivation of primary intestinal cells from Eisenia fetida}

Unless otherwise indicated, freshly isolated cells were cultivated in a medium formulation consisting of $60 \%(\mathrm{v} / \mathrm{v})$ L-15 medium, $20 \%(\mathrm{v} / \mathrm{v})$ cell culture grade water, $10 \%(\mathrm{v} / \mathrm{v})$ FCS, and $10 \%(\mathrm{v} / \mathrm{v})$ worm filtrate (WF), supplemented with $4 \mathrm{mM}$ L-glutamine, $25 \mathrm{mM}$ HEPES, and PSTGA. The osmolality of the culture media was measured using an Osmomat 030 (Gonotec GmbH, Berlin, Germany) 
according to the manufacturer's instructions (indicated reproducibility: $< \pm 0.5 \%)$. Two standards $(0$ and $850 \mathrm{mOsmol} / \mathrm{kg}$ ) were used for calibration. Worm filtrate was sterilized directly before use by $2 \times$ filtration through a sterile filter $(0.2 \mu \mathrm{m}$ cellulose acetate). Cells were seeded at a density of 0.3 to $0.4 \times 10^{6}$ cells/well for 24 well plates and of 0.1 to $0.15 \times 10^{6}$ cells/well for 48 well plates. To reduce evaporation during the cultivation, wells on the edge of the plate were filled with sterile ultrapure water. The plate was incubated in the dark in an airtight box containing a reservoir of sterile ultrapure water at room temperature (20 to $22{ }^{\circ} \mathrm{C}$ ) for L-15 medium or at $37^{\circ} \mathrm{C}$ in a humidified atmosphere containing $5 \% \mathrm{CO}_{2}$ for Schneider's medium formulations. To routinely observe cell growth and morphology, an inverse microscope was used (Primovert, Carl Zeiss Microscopy $\mathrm{GmbH}$, Jena, Germany). Images were recorded using an Axiocam 105 color camera and the ZEN 3.0 (blue edition) software. Cell number, size and viability were determined using the automated cell counter LUNA-FL ${ }^{\mathrm{TM}}$ Dual Fluorescence Cell Counter (Logos Biosystems, Gyeonggi-do, South Korea). Acridine orange and propidium iodide fluorescence staining was performed according to the manufacturer's instructions.

\section{Coating of cell culture plates}

To promote cell adherence, various coatings for cell culture plates were tested. The coating procedure was performed under sterile conditions in a biosafety cabinet for 24 well cell culture plates (surface area $1.9 \mathrm{~cm}^{2}$ per well); all wells were rinsed with sterile ultrapure water before coating to reduce surface tension. The detailed coating strategy is given in Table S2. After addition of the respective coating solution to the well, the plate was swiveled to distribute the liquid evenly over the entire surface and the plate was incubated for the indicated time at the indicated temperature. Afterwards, the remaining solution was aspirated and-in case of the Poly-L-lysine coating - the well was rinsed four times with sterile ultrapure water. All wells were allowed to dry for $2 \mathrm{~h}$ under sterile conditions with half-open lid before introducing medium and cells. Collagen coated wells were rinsed twice with sterile DPBS prior to use.

\section{MTT-assay for metabolic activity of the primary intestinal cells}

0.1 to $0.15 \times 10^{6}$ cells/well in $500 \mu \mathrm{L}$ culture medium were seeded immediately after isolation in 48 well plates and cultivated for $48 \mathrm{~h}$ or $96 \mathrm{~h}$ as indicated. $50 \mu \mathrm{L}$ of a freshly prepared, sterile filtrated solution of $10 \mathrm{mg} / \mathrm{mL}$ MTT reagent in M-HBSS buffer were added $24 \mathrm{~h}$ before measurement to each well (final MTT concentration: $1 \mathrm{mg} / \mathrm{mL}$ ) and the cells were further incubated. $24 \mathrm{~h}$ after MTT addition, the cells were harvested in reaction tubes and centrifuged at $400 \times g$ for $5 \mathrm{~min}$. The supernatant was discarded and the cells containing the formed formazan crystals were resuspended in $250 \mu \mathrm{L}$ isopropanol. The suspension was split evenly into two wells of a 96 well plate. After $5 \mathrm{~min}$ agitating $(600 \mathrm{rpm}, \mathrm{MS} 2$ Minishaker, IKA, Staufen im Breisgau, Germany), the absorbance at $570 \mathrm{~nm}$ (reference wavelength $650 \mathrm{~nm}$ ) was measured using a TECAN GENios Pro plate reader (Tecan Austria GmbH, Gröding, Austria). The MTT assay was also used to determine the effects of the $\mathrm{Ag}$ nanoparticles $(1,3$, and $6 \mu \mathrm{g} / \mathrm{mL})$, the $\mathrm{Cu}^{2+}$ (40 and $\left.400 \mu \mathrm{g} / \mathrm{mL}\right)$ and the $\mathrm{Cd}^{2+}(80$ and $800 \mu \mathrm{g} /$ $\mathrm{mL})$ ions, as well as the MP particles $(2.5 \mu \mathrm{g}$ MPP and $250 \mu \mathrm{g}$ per $0.1 \times 10^{6}$ cells) on the isolated intestinal cells. Detailed information of Ag nanoparticles and MP particle concentrations and numbers are given in Tables S3, S4. An additional citrate control (final concentration of $0.6 \mathrm{mM}$ sodium citrate in culture medium) was used to determine effects of the solvent used for Ag nanoparticle suspension and to separate these effects from those of the investigated putative cytotoxins. Ag nanoparticles, metal ions, or MP particles were added immediately after cell seeding. Cells incubated without particles/metal ions were used as a negative control (normalizing condition).

\section{Microplastic particle uptake studies}

For MP particle uptake studies, freshly isolated cells were cultivated for $48 \mathrm{~h}$ in the presence of $2.5 \mu \mathrm{g}$ fluorescent MP particles per $0.1 \times 10^{6}$ cells. Uptake was verified by confocal laser scanning microscopy ((TCS SP8, 63x oil objective, laser: $408 \mathrm{~nm}, 488 \mathrm{~nm}$, and $552 \mathrm{~nm}$, Leica Microsystems, Wetzlar, Germany). Cells were fixed with $3.7 \%$ (v/v) paraformaldehyde in DPBS at $37^{\circ} \mathrm{C}$ for $10 \mathrm{~min}$. Afterwards, the cells were centrifuged $(180 \times g$ for $5 \mathrm{~min})$ and washed once with DPBS. Next, the cells were permeabilized with $0.1 \%$ (v/ v) Triton X-100 at room temperature for $15 \mathrm{~min}$. After a further wash with DPBS, the cells were stained for $1 \mathrm{~h}$ at room temperature with $100 \mathrm{nM}$ rhodamine-phalloidin (Phalloidin-Tetramethyl rhodamine B isothiocyanate, supplier Sigma Aldrich) for actin filament staining and $100 \mathrm{nM}$ DAPI (4',6-diamidino-2-phenylindole, supplier Sigma Aldrich) for staining of the nuclei. After the staining procedure, another washing step was performed and the cells were seeded in Ibidi slides (Gräfelfing, Germany) for microscopy. The samples were analyzed by confocal laser scanning microscopy; Z-stacks were taken with a step size of $0.33 \mu \mathrm{m}$.

\section{Measurement of $\zeta$-potential and particle size by dynamic light scattering (DLS)}

$\zeta$-potential measurements of the particles' surface charges were performed using the LiteSizer 500 and Omega 
cuvettes (both Anton Paar Germany GmbH, OstfildernScharnhausen, Germany). $2.5 \mu \mathrm{L}$ of the MP particle suspensions or $70 \mu \mathrm{L}$ of the $\mathrm{Ag}$ nanoparticle suspension were diluted in $1 \mathrm{~mL}$ of a $1 \mathrm{mM}$ aqueous $\mathrm{KCl}$ solution ( $\mathrm{pH} 6.0$ ) and measured immediately. In addition, $2.5 \mu \mathrm{L}$ of the MP particle suspensions or $70 \mu \mathrm{L}$ of the $\mathrm{Ag}$ nanoparticle suspension were incubated in $1 \mathrm{~mL}$ of the final culture medium overnight at room temperature. Thereafter, the particles were collected by centrifugation $(17,000 \times g, 40 \mathrm{~min})$ and resuspended in $1 \mathrm{~mL}$ of a $1 \mathrm{mM} \mathrm{KCl}$ solution for measurement. Three measurements with at least 100 runs each were performed at $21^{\circ} \mathrm{C}$ with an adjusted voltage of $200 \mathrm{~V}$. The $\zeta$-potential was calculated using the HelmholtzSmoluchowski equation (von Smoluchowski 1906). For dynamic light scattering (DLS), $2.5 \mu \mathrm{L}$ of the MP particle suspensions or $70 \mu \mathrm{L}$ of the Ag nanoparticle suspension were diluted in $1 \mathrm{~mL}$ of a $1 \mathrm{mM}$ aqueous $\mathrm{KCl}$ solution (pH 6.0). The measurements with at least 10 runs each at $21^{\circ} \mathrm{C}$ in the backscatter mode (angle $175^{\circ}$ ) were performed using the same device as for the $\zeta$-potential measurements.

\section{Statistical analyses}

All statistical analyses were conducted using the statistical platform $\mathrm{R}$ version 4.0.3. ( $\mathrm{R}$ Core Team 2020). To test the influence of different buffers on viability and cell yield, we used a Kruskal-Wallis test in addition with the dunn.test package (Dinno 2017) as a post-hoc comparison. Using a linear model (LM) with the Tukey post-hoc comparison from the multcomp package (Hothorn et al. 2008), we tested the impact of different combinations and concentrations of FCS and WF on the metabolic activity of the earthworm intestinal cells. The same procedure was used to check the influence of MP particle, Ag particle, and metal ion exposure on the cells' metabolic activity. In all whisker boxplots the 25 and $75 \%$ quartile are presented with the whiskers representing the maximal and minimal values. Outliers are defined as 1.5 times the value of the 25 and $75 \%$ quartile threshold and are represented as points outside the boxplot. Median is indicated as a black line and mean value as a white circle.

\section{Results and discussion}

\section{Isolation of primary intestinal cells of Eisenia fetida}

In order to obtain a maximum number of vital cells from the intestinal tissue of E. fetida, a gentle yet efficient release procedure was established (Fig. 1). Based on previous experience with the release of primary cells from tissue, an enzyme-supported tissue disaggregation step was implemented in the protocol using collagenase II. Collagenase can effectively break down peptide bonds present in collagen, which is the main structural component in the extracellular matrix (ECM) (Rahman 2019; Ricard-Blum 2011).

Composition and in particular osmolality of the buffer receiving the released cells are of major importance for final cell yield and vitality. Here, two buffers were compared for the initial preparation of the intestinal tract as well as the enzymatic treatment. Both buffers, namely M-HBSS and LBSS, had previously been used to collect coelomocytes from E. fetida and other earthworm species (Diogène et al. 1997; Engelmann et al. 2004; Eyambe et al. 1991; Irizar et al. 2014; Stein and Cooper 1981). With $210 \mathrm{mOsmol} / \mathrm{kg}$ M-HBSS has a slightly higher osmolality than LBSS $(171 \mathrm{mOsmol} / \mathrm{kg})$, but both buffers should be in an acceptable range. Further, M-HBSS contains $5.5 \mathrm{mM}$ glucose as potential C-source and $10 \mathrm{mM}$ HEPES as additional buffering agent, whereas LBSS contains no C-source and only very low concentrations $(0.4 \mathrm{mM})$ of phosphate as possible buffering agent (Table S1).

No statistically relevant difference in regard to cell viability could be found between the two buffer systems (Kruskal-Wallis-Test: $\chi^{2}=4.42$, p-value $=0.11$ ) (Fig. 2A). The isolated cells had a cell size between 5.9 and $20.7 \mu \mathrm{m}$ (median $11.9 \mu \mathrm{m}$, mean $12.6 \pm 3.4 \mu \mathrm{m}$ ). The viability was $>70 \%$ in all cases $(n \geq 4)$, which we considered sufficient for subsequent cultivations. However, there was a trend towards higher viabilities for cells isolated in M-HBSS (median $87.2 \%$ for M-HBSS ( $\mathrm{n}=11$ ) vs. $79.8 \%$ for LBSS $(n=4))$. The presence of glucose as a possible carbon source for the isolated cells in case of M-HBSS was most

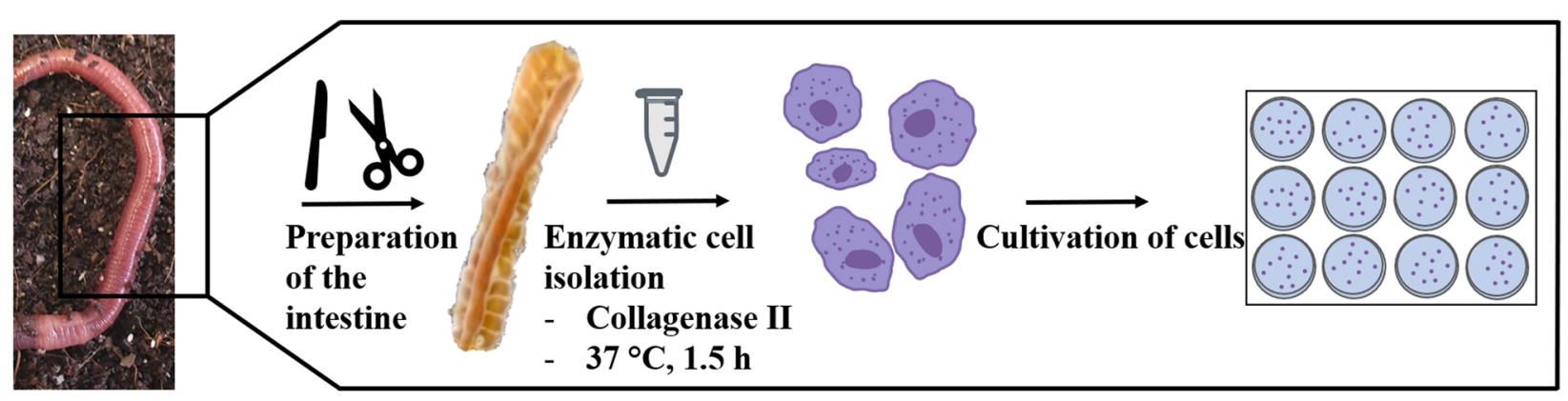

Fig. 1 Experimental workflow for the isolation of primary intestinal cells from the earthworm E. fetida 

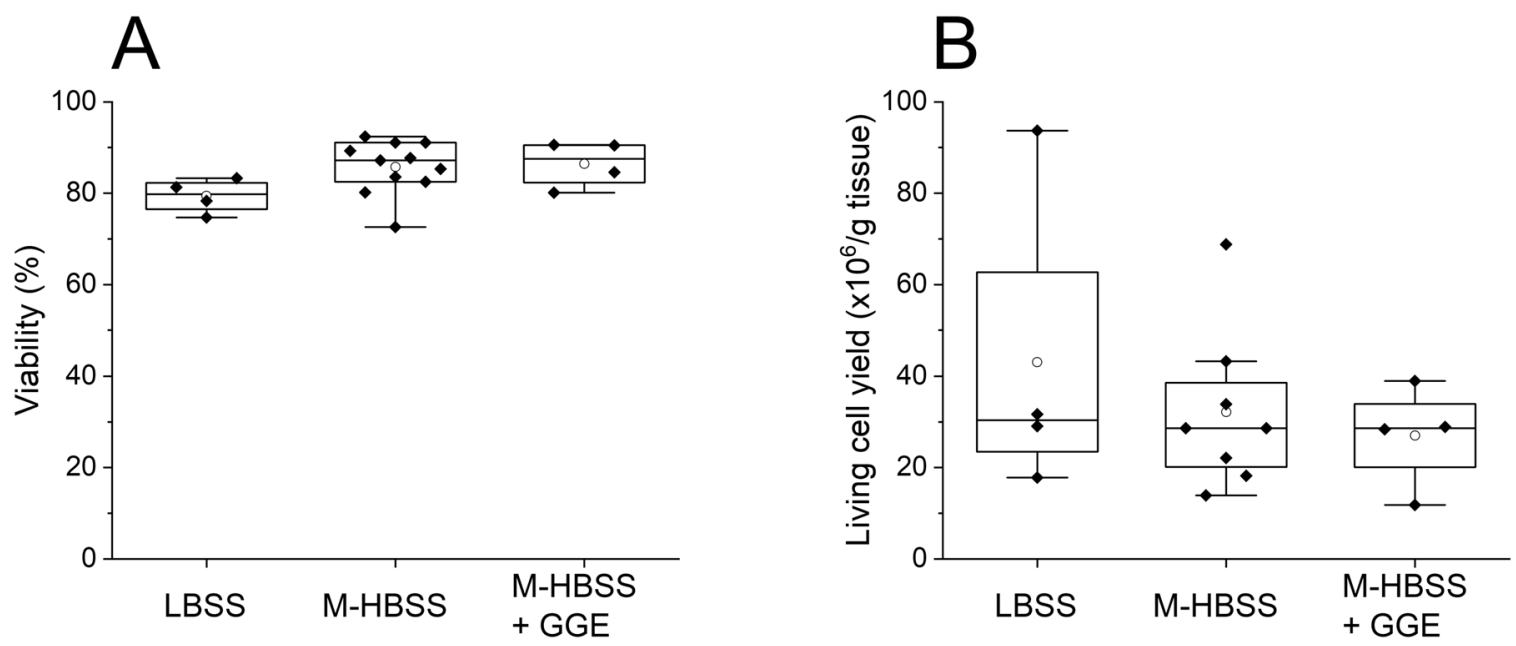

Fig. 2 Comparison of LBSS and M-HBSS, as well as M-HBSS, supplemented with $50.4 \mathrm{mM}$ GGE for isolation of primary intestinal cells from E. fetida. A Viability of the isolated intestinal cells, B Living cell yield. $n \geq 4$

likely responsible for this small but noticeable effect. It is also possible that the higher buffering capacity of M-HBSS helped to stabilize the cells. The living cell yields (Fig. 2B) varied strongly between individual experiments, ranging from $11.8 \times 10^{6}$ to $93.7 \times 10^{6}$ living cells per gram of tissue. The buffer, either M-HBSS or LBSS, again had no significant influence on the average cell yield (Kruskal-WallisTest: $\chi^{2}=0.68, \mathrm{p}$-value $=0.71$, but the deviations were much more pronounced in case of LBSS. The more easily exhausted buffer capacity of the LBSS buffer may well have contributed to the low reproducibility of the protocol. Therefore, M-HBSS was used in further experiments.

Next, the impact of adding a mucolytic agent during the enzymatic digestion was tested, namely Guaiacol Glyceryl Ether (GGE). GGE is often used for coelomocyte isolation (Diogène et al. 1997; Engelmann et al. 2004; Eyambe et al. 1991) and dissolves in particular mucus-like tissue. When M-HBSS in the absence and presence of GGE (50.4 mM as proposed previously (Diogène et al. 1997)) was used in independent experiments $(n \geq 4)$, the results showed no significant influence of GGE on the isolation process, as neither viability (Dunn post-hoc comparison: $p$-value $=0.48$ ) nor living cell yield (Dunn post-hoc comparison: $\mathrm{p}$-value $=0.35$ ) was affected (Fig. 2). Therefore, GGE was not used in subsequent experiments.

\section{Cultivation of isolated primary intestinal cells from E. fetida}

For the cultivation of the isolated primary cells, a suitable (basal) culture medium in terms of nutrients, osmolality, buffer system and capacity, as well as $\mathrm{pH}$ had to be identified. Moreover, in preliminary cultivation experiments with isolated primary cells, microbial contaminations of the cell culture were observed. This is not surprising, given that earthworms are known for their complex intestinal microbiome (Pass et al. 2015). As earthworms are soil feeders, a high number of bacteria and fungi must be expected in the intestinal tract. Washing steps during the isolation were not sufficient to deplete the microbial burden; presumably microbes were embedded and protected in a mucus layer. Better results were obtained after the addition of a complex mixture of antibiotics (penicillin, streptomycin, tetracycline, gentamycin) together with the antimycotic amphotericin B to the medium (hereafter referred to as PSTGA). PSTGA was supplemented during cell isolation and cultivation and securely prevented microbial contamination for at least $144 \mathrm{~h}$.

Our attempts to identify a suitable basal medium were based on published media formulations (Battaglia and Davoli 1997; Bilej et al. 1990; Engelmann et al. 2004; Gong et al. 2014; Irizar et al. 2014; Roch et al. 1975; Toupin et al. 1977), mostly L-15 and SDM (standard compositions are shown in Table S5), which are summarized in Table 1. Cultivation experiments with L-15 medium were performed at room temperature without additional $\mathrm{CO}_{2}$, whereas in case of the SDM based formulations $37^{\circ} \mathrm{C}$ and an atmosphere containing $5 \% \mathrm{CO}_{2}$ were used, as described in literature (Gong et al. 2014; Irizar et al. 2014).

Cell number and viability were analyzed over $144 \mathrm{~h}$ of cultivation (data not shown). While no increase in cell number was observed in any of the media formulations over the cultivation time, cell viability remained $>90 \%$, showing that the cells could be kept alive for at least $144 \mathrm{~h}$. As no medium was clearly superior to the others, cultivation in L-15 medium at room temperature was chosen as the simplest approach for further experiments. L-15 medium allows cell cultivation without the sodium carbonate/carbon dioxide buffering system as it utilizes free base amino acids (L-arginine, L-histidine, Lcysteine) as buffering agents (Leibovitz 1963). Cultivation at room temperature accommodates $E$. fetida primary cells, since 
Table 1 Media a investigated in the cultivation experiments

\begin{tabular}{llllccc}
\hline & $\begin{array}{l}\text { Basal medium } \\
(\% \mathrm{v} / \mathrm{v})\end{array}$ & $\mathrm{FCS}^{\mathrm{b}}(\% \mathrm{v} / \mathrm{v})$ & $\begin{array}{l}\text { Cell culture grade } \\
\text { water }(\% \mathrm{v} / \mathrm{v})\end{array}$ & Galactose $(\mathrm{g} / \mathrm{L})$ & Lactalbumin hydrolysate $(\mathrm{g} / \mathrm{L})$ & Osmolality ${ }^{\mathrm{c}}(\mathrm{mOsmol} / \mathrm{kg})$ \\
\hline L-15-10 & 90 & 10 & - & - & - & $339 \pm 4$ \\
L-15-10-GLA & 90 & 10 & - & 1.3 & 4.5 & $345 \pm 3$ \\
SDM & & - & $326 \pm 9$ \\
SDM-13-GLA & 87 & 13 & - & - & 4.5 & $344 \pm 2$ \\
Hansen S-301 & 22 & 13 & - & 1.3 & 4.5 & $157 \pm 5$ \\
\hline
\end{tabular}

${ }^{a}$ All media were supplemented with PSTGA. When indicated, media were in addition supplemented with galactose and lactalbumin hydrolysate (GLA) using a concentrated stock solution $(200 \mathrm{~g} / \mathrm{L})$. L-15 media were supplemented with $4 \mathrm{mM}$ L-glutamine

${ }^{\mathrm{b}}$ FCS: Fetal calf serum

${ }^{c}$ Osmolality is shown as mean $\pm \mathrm{SD}(n=5)$

${ }^{\mathrm{d}}$ SDM: Schneider's Drosophila Medium

the natural habitat of E. fetida is the soil, and laboratory cultures are commonly kept at temperatures between 15 and $20^{\circ} \mathrm{C}$ (Miles 1963; Presley et al. 1996; Tripathi and Bhardwaj 2004). For coelomocytes from the congeneric E. hortensis, an increase in temperature above $25^{\circ} \mathrm{C}$ is known to significantly increase cell death rates (Fuller-Espie et al. 2015). Strikingly, this was not observed here for the intestinal cells, which survived well when cultivated in SDM based media at $37^{\circ} \mathrm{C}$.

The addition of HEPES did not influence cell number or viability (data not shown), but had a beneficial effect on the reproducibility of the experiments, presumably due to the higher buffering capacity. Therefore, the medium was supplemented with HEPES in the subsequent experiments.

Although cell numbers varied slightly during cultivation, significant proliferation was never observed, including the SDM based preparations, which had previously been proposed to support proliferation of intestinal cells from another earthworm species (Gong et al. 2014). Proliferation is not necessary for ecotoxicology experiments, but may be useful in other types of research. The observed lack of proliferation could be explained by a lack of specific growth factors for E. fetida cells in the basal culture medium. For primary cells, specific growth factors are typically supplied via blood serum or cell homogenate. Here, an investigative three-step adaption into that direction was performed comprising (1) a supplement screening involving worm filtrate (WF), but also fetal calf serum (FCS) as a standard media additive in mammalian cell culture, (2) an adaption of the osmolality, and finally 3) a verification of the appropriate conditions by measuring the metabolic activity.

First, we recorded cell number and viability at different concentrations and combinations of FCS and WF in cultivation experiments (Fig. 3A). L-15 medium without additive yielded a slight reduction of cellular viability over time, albeit never dropping below $80 \%$. Both FCS or WF appeared to slightly improve cell viability. Since there was no clear difference between WF and FCS as additive, we chose a mixture of $10 \%$ FCS and $10 \% \mathrm{WF}$ as starting composition for the osmolality adaption, evaluating different dilutions of L-15 medium for cultivation, corresponding to final osmolalities between 308 and $381 \mathrm{mOsmol} / \mathrm{kg}$ (Table S6). In the subsequent cultivation experiments, there was no clear influence of the medium dilutions on cell number or viability (data not shown). For the common earthworm Aporrectodea caliginosa, a broad range of body fluid osmolality from 175 to $684 \mathrm{mOsmol} / \mathrm{kg}$ was measured for different dehydration states suggesting a high tolerance of that species against a broad range of osmolalities (Bayley et al. 2010). Therefore, L-15-60\% $(10 \% \mathrm{v} / \mathrm{v}$ FCS and WF, $60 \%$ v/v L-15, $20 \% \mathrm{v} / \mathrm{v}$ cell culture grade water) was chosen for further experiments, as its osmolality of approximately $310 \mathrm{mOsmol} / \mathrm{kg}$ was considered to be closest to characteristic osmolalities of terrestrial animals (Stankiewicz and Plytycz 1998).

Cellular vitality, i.e., metabolic activity, is an equally important indicator for cell cultivation and toxicity testing. Using L-15-60\% as basis, the impact of the FCS/WF supplement on cellular vitality was investigated using the MTT assay as analytical tool (Fig. 3B). Cells cultivated in $10 \%$ FCS $+10 \%$ WF or $20 \%$ FCS reached the highest mitochondrial metabolic activity, i.e., $150 \%$ compared to that in L-15-60\% without FCS/WF supplementation. The difference was statistically significant $\left(\mathrm{LM}_{\text {Treatment }} \mathrm{F}_{5}=4.706\right.$, pvalue $<0.004$, Tukey post-hoc comparison: p-value $10 \%$ FCS + $10 \% \mathrm{WF}=0.027, \mathrm{p}$ - value $_{20 \% \mathrm{FCS}}=0.002$ ). L-15-60\%, supplemented with $10 \%$ FCS, $10 \% \mathrm{WF}$, as well as $4 \mathrm{mM} \mathrm{L-}$ glutamine, $25 \mathrm{mM}$ HEPES, and PSTGA was therefore chosen as standard culture medium for E. fetida cells.

Cell seeding density is a critical factor for primary cell cultivation, as a sufficient number of cells is needed for cell-cell interactions as well as for the production of autocrine growth factors. However, in the case of primary cells, proliferation often stops once confluency is reached during cultivation. Therefore, the effect of seeding cell densities was analyzed microscopically for seeding cell densities between $0.053 \times 10^{6} \mathrm{cells} / \mathrm{cm}^{2}$ and $0.421 \times 10^{6}$ cells $/ \mathrm{cm}^{2}$ in 24 well plates with $1 \mathrm{~mL}$ culture medium (Fig. 4). 
In these experiments, cell seeding densities between $0.158 \times 10^{6} \mathrm{cells} / \mathrm{cm}^{2}$ and $0.210 \times 10^{6} \mathrm{cells} / \mathrm{cm}^{2}$ were optimal. Lower seeding densities led to large, uncovered areas, whereas higher cell densities resulted in an increased number of floating cell aggregates after $48 \mathrm{~h}$. This seeding density is in accordance with previously published results using $P$. aspergillum primary epithelial cells (Gong et al. 2014)

The occurrence of floating cellular aggregates indicated that the cells failed to properly adhere to the cell culture plate. Adherence is an important factor for growth of intestinal cells considering that these cells are derived from epithelial tissue. To promote adherence of the isolated cells to the culture plate, different coating strategies were evaluated based on standard cell culture coating materials, in particular poly-L-lysine, gelatin (porcine), collagen type I (human) and collagen type II (bovine) (Davidenko et al. 2016; Harnett et al. 2007; Liberio et al. 2014). None of the treatments improved cell adhesion. We currently assume that the lack of suitable adhesion factors

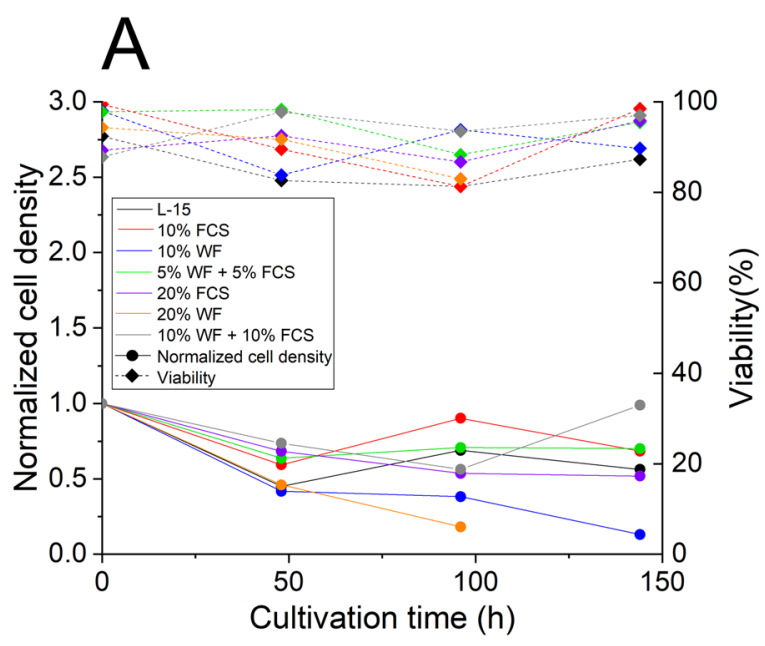

Fig. 3 Cultivation of primary intestinal cells of E. fetida in media formulations containing the indicated amounts of FCS and/or WF. A Representative cultivations with normalized cell density to the seeding cell density and viability for cultivation in the indicated media over time. B Metabolic activity of primary intestinal cells after 48 and $96 \mathrm{~h}$ is a major contribution to the lack of proliferation observed for the intestinal cells.

\section{Ecotoxicity testing using primary intestinal cells of E. fetida}

Even in the absence of proliferation, highly viable, metabolically active primary cells present an excellent basis for a study of acute toxic effects of common ecotoxins on the cellular level. For a demonstration, we examined the influence of known environmental pollutants, namely $\mathrm{Ag}$ nanoparticles and metal ions $\left(\mathrm{Cu}^{2+}, \mathrm{Cd}^{2+}\right)$ on the metabolic activity of the isolated cells (Fig. 5).

For the intestinal cells, exposure to Ag nanoparticles led to a slight, but significant decrease in metabolic activity $\left(\mathrm{LM}_{\text {Treatment }} \mathrm{F}_{9}=4897 ; \mathrm{p}<0.001\right)$ in a concentrationdependent manner compared to the negative control (cells in culture medium) (Tukey post-hoc comparison: $\mathrm{p}$ - alue $_{48 \mathrm{~h}}=$ 0.130, p-value $96 \mathrm{~h}=0.084)$ (Fig. 5A). Cells exposed to the

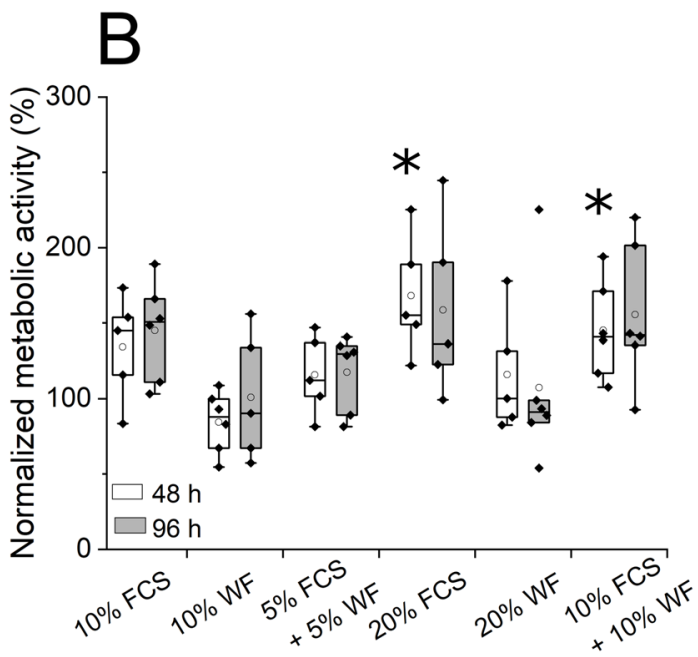

of cultivation in the indicated media. Shown is the metabolic activity normalized to L-15-60\% without FCS and/or WF supplementation. $n \geq 5$. Statistically significant differences to the negative control are indicated by $*$
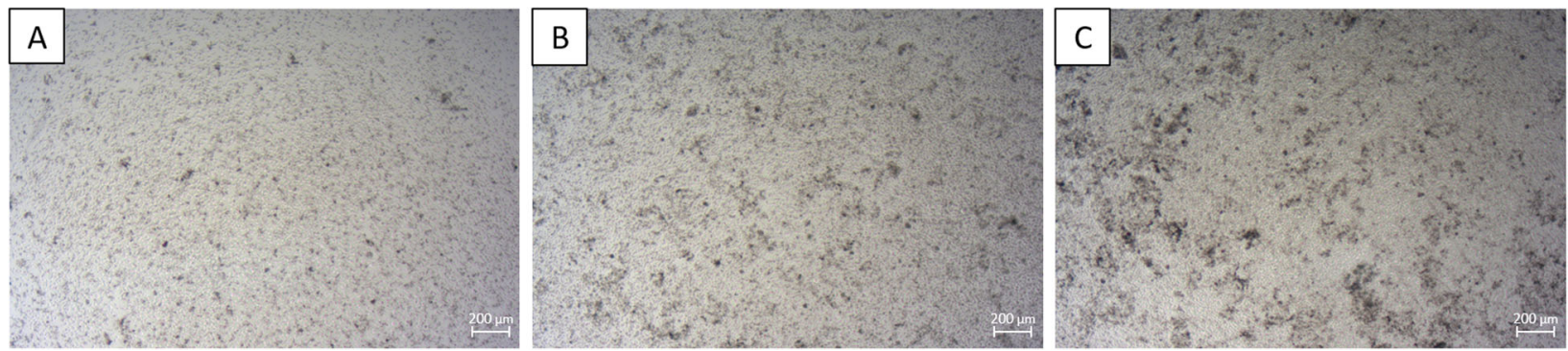

Fig. 4 Representative microscopical images of primary intestinal cells seeded at different cell densities after $48 \mathrm{~h}$ of cultivation in 24 well plates. A Cell seeding density: $0.053 \times 10^{6}$ cells $/ \mathrm{cm}^{2}$. B Cell seeding density: $0.210 \times 10^{6}$ cells $/ \mathrm{cm}^{2}$. C Cell seeding density: $0.421 \times 10^{6}$ cells $/ \mathrm{cm}^{2}$. Scale bar $=200 \mu \mathrm{m}$ 


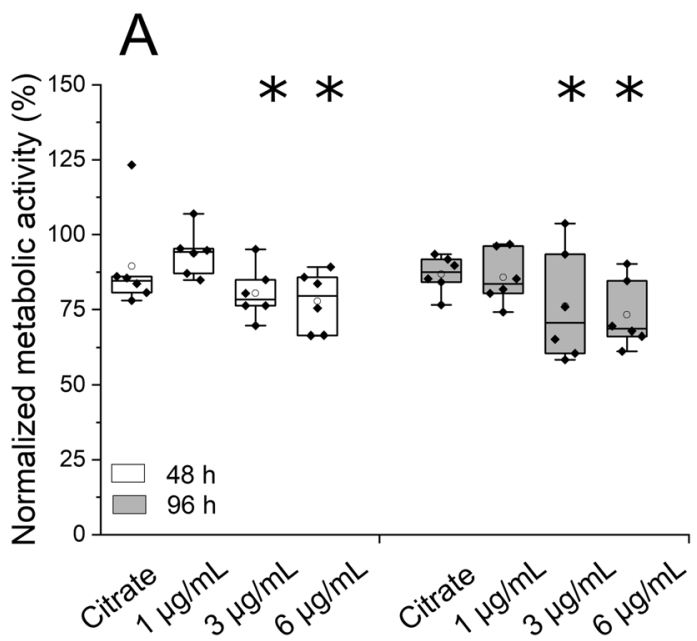

Fig. 5 Influence of (A) Ag nanoparticles and (B) metal ions on the metabolic activity of primary intestinal cells from E. fetida analyzed using the MTT assay after 48 and $96 \mathrm{~h}$ of incubation. Shown is the metabolic activity of cells normalized to a negative control (cells

citrate buffer used to suspend the Ag nanoparticles ("citrate control", amount corresponding to $6 \mu \mathrm{g} / \mathrm{mL} \mathrm{Ag} \mathrm{nanoparticles)}$ also showed a reduced metabolic activity, but the effect was clearly enhanced in presence of 3 or $6 \mu \mathrm{g} / \mathrm{mL} \mathrm{Ag} \mathrm{nano-}$ particles. On the organismic level, Ag nanoparticles show only slight to negligible effects on traditional ecotoxicological endpoint markers like growth, mortality and reproduction of $E$. fetida (Kwak et al. 2014; Shoults-Wilson et al. 2011). Kwak et al. (2014) demonstrated the importance of the nanoparticular material, since Ag nanoparticles showed a slight effect on $E$. andrei while the exposure to pure Ag ions showed no effect at all. On the other hand, isolated coelomocytes of E. fetida cultivated in RPMI-1640 medium showed an $\mathrm{LC}_{50}$ value of $6 \mu \mathrm{g} / \mathrm{mL}$ (Garcia-Velasco et al. 2019). Coelomocytes cultivated in L-15 medium, on the other hand, showed a much higher resistance to $\mathrm{Ag}$ nanoparticles $\left(\mathrm{LC}_{50}>100 \mu \mathrm{g} / \mathrm{mL}\right)$ (Garcia-Velasco et al. 2019). Differences between the studies may stem from differences in particle size as well as different cell types used and therefore non-comparable cellular reactions. In the end only additional studies on the cellular level can elucidate the mechanistic basis for the observed toxic effects.

In contrast to particles, whose size and surface coverage are known to have a significant effect on toxicity, metal ions are considered to be more standardizable toxins. The response of the cells to copper and cadmium ions are summarized in Fig. 5B. The results show a significant decrease in metabolic activity for all tested concentrations $\left(\mathrm{LM}_{\text {Treatment }} \mathrm{F}_{8}=5.027, \mathrm{p}<0.001\right)$, except $800 \mu \mathrm{g} / \mathrm{mL}$ $\mathrm{CdCl}_{2}$ after $48 \mathrm{~h}$ exposure. After $96 \mathrm{~h}$ the cells seemed to recover to some extent, but the metabolic activity was still low compared to the controls. A more pronounced effect had been expected in particular for the respective

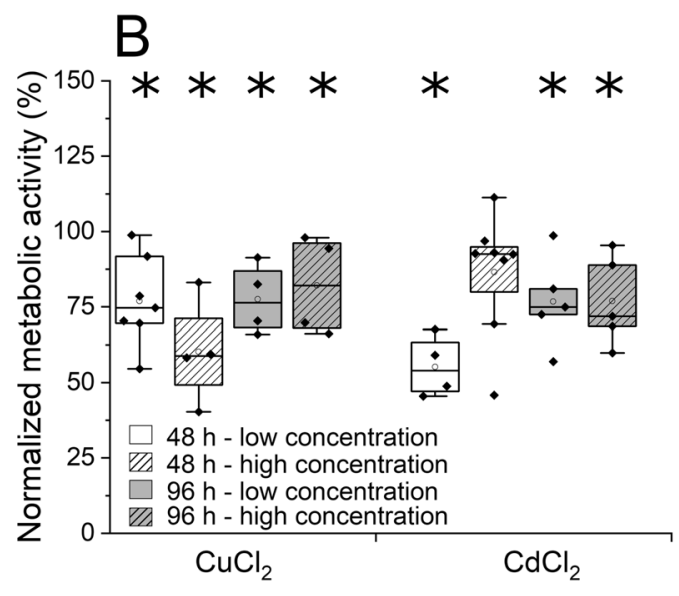

incubated without particles or metal ions). $n \geq 3$. Statistically significant differences to the negative control) are indicated by $* . \mathrm{CuCl}_{2}$, low concentration: $40 \mu \mathrm{g} / \mathrm{mL}$, high concentration: $400 \mu \mathrm{g} / \mathrm{mL} \mathrm{CdCl}_{2}$, low concentration: $80 \mu \mathrm{g} / \mathrm{mL}$, high concentration: $800 \mu \mathrm{g} / \mathrm{mL}$

higher metal ion concentrations, i.e., $400 \mu \mathrm{g} / \mathrm{mL} \mathrm{CuCl}_{2}$ and $800 \mu \mathrm{g} / \mathrm{mL} \mathrm{CdCl}_{2}$, since these are already in the range of the median lethal concentration for E. fetida in soil, namely $500-700 \mathrm{mg} / \mathrm{kg}$ soil for copper and $600-1800 \mathrm{mg} / \mathrm{kg}$ soil for cadmium (Bernard et al. 2015; Neuhauser et al. 1985). Interestingly, coelomocytes isolated from E. fetida showed a similar response at least to changing cadmium doses, where the viability decreased in the presence of $100 \mu \mathrm{g} / \mathrm{mL}$ followed by an increase in viability at concentrations of $500 \mu \mathrm{g} / \mathrm{mL}$ (Irizar et al. 2015). Irizar et al. (2015) assumed that different stress mechanism exist for E.fetida, which might also play a role in the recovery of the cells after a longer incubation with $\mathrm{Cd}$. However, no specific mechanisms are known yet. The discrepancy between organismic effects and the reactions described here suggest different toxicological mechanisms on different levels of biological complexity. Our work provides a basis to analyze these mechanisms on a cellular level for intestinal cells.

\section{Effects of MP particles on primary intestinal cells isolated from $E$. fetida}

Finally, the influence of MP particles was investigated on the cells as an example of a new and increasingly important environmental pollutant with particular relevance for unspecific soil feeders such as E. fetida. PS microparticles were chosen as representatives of non-biodegradable commodity plastics, whereas PLA microparticles were chosen as example for a biodegradable polymer. The possibility of a cellular uptake of the particles was also studied, using particle sizes between 0.2 and $3 \mu \mathrm{m}$.

Surface properties and in particular a biomolecular corona on the particle's surface have recently been suggested 
as decisive for cell particle interaction and uptake (Ramsperger et al. 2020). Therefore, once the MP particles are added to the cells in the protein-rich culture medium the formation of a protein corona is likely. $\zeta$-potentials and size distribution measured of MP particles incubated at various conditions are summarized in Table 2.

Incubation in culture medium led to a reduction of the $\zeta$-potential. Even particles with significantly different $\zeta$-potential before incubation showed similar ones after incubation in culture medium independent of the particle diameter. This indicates the development of a similar protein corona on the surface of all investigated PS particles. Pristine PLA particles, on the other hand, initially showed a small negative $\zeta$-potential, which was slightly increased in case of the $2 \mu \mathrm{m}$ particles after incubation. As expected, the PLA particles were colloidally instable due to the low $\zeta$-potential, and thereby the size of the PLA particles nearly doubled after incubation in the culture medium and the size distribution became wider.
Within the 24 exposure experiments (Fig. 6), only cells incubated at high concentrations of $2 \mu \mathrm{m}$ PS particles showed a significantly reduced metabolic activity after $48 \mathrm{~h}$ of incubation $\left(\mathrm{LM}_{\text {Treatment }} \mathrm{F}_{24}=2.291, \mathrm{p}=0.004\right.$, Tukey post-hoc comparison: p-value $2 \mu \mathrm{m}$ PS $=0.025$ ). In the presence of $0.5 \mu \mathrm{m}$ PLA at the high concentration after $48 \mathrm{~h}$ the cells even showed a significantly higher metabolic activity $\left(\mathrm{LM}_{\text {Treatment }} \mathrm{F}_{24}=2.291, \mathrm{p}=0.004\right.$, Tukey post-hoc comparison: $\mathrm{p}$ - value $_{0.5} \mu \mathrm{m}$ PLA $=0.006$ ). This finding seems counterintuitive, however correlations between dose and response may not necessarily be linear as already shown for E. fetida on the organismic level (Chen et al. 2020; Jiang et al. 2020), as well as for coelomoycetes (Irizar et al. 2015).

Finally, confocal microscopy showed no apparent uptake of fluorescent MP particles of any type and size by the cells. Particles $\leq 0.5 \mu \mathrm{m}$ showed some tendency of attachment to the cellular membranes, however, no signs of uptake or attachment were seen for larger particles (Fig. 7). This might also explain the observed low effect of the particles
Table $2 \zeta$-potential and size distribution measured for the MP particles used in this study

\begin{tabular}{llllll}
\hline Nominal particle size $(\mu \mathrm{m})$ & \multicolumn{2}{l}{$\zeta$-potential $(\mathrm{mV})$} & & \multicolumn{2}{l}{ Measured particle size $(\mu \mathrm{m})$} \\
\cline { 2 - 3 } & $\mathrm{KCl}$ & Culture medium & & $\mathrm{KCl}$ & Culture medium \\
\hline PS & & & & \\
0.2 & $-47.4 \pm 0.3$ & $-25.3 \pm 0.0$ & & $0.2 \pm 0.006$ & $0.2 \pm 0.008$ \\
0.5 & $-52.8 \pm 0.2$ & $-27.6 \pm 0.0$ & & $0.5 \pm 0.008$ & $0.6 \pm 0.04$ \\
2 & $-76.7 \pm 0.3$ & $-28.8 \pm 0.0$ & & $1.8 \pm 0.03$ & $1.5 \pm 0.04$ \\
3 & $-78.9 \pm 0.3$ & $-29.3 \pm 0.2$ & & $3.1 \pm 0.08$ & $3.3 \pm 0.1$ \\
PLA & & & & \\
0.5 & $-1.1 \pm 0.0$ & $-1.3 \pm 0.4$ & & $0.6 \pm 0.02$ & $1.1 \pm 0.1$ \\
2 & $-3.9 \pm 0.3$ & $-11.2 \pm 1.1$ & & $1.5 \pm 0.2$ & $2.4 \pm 1.2$ \\
\hline
\end{tabular}

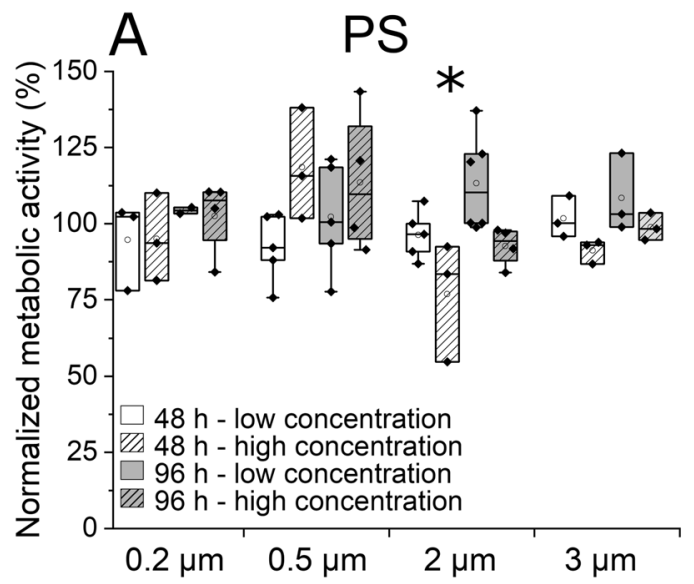

Fig. 6 Influence of MP particles (MPP) on the metabolic activity of primary intestinal cells from E. fetida after 48 and $96 \mathrm{~h}$ incubation time. A Influence of PS particles on cells incubated with $2.5 \mu \mathrm{g}$ MPP/ $0.1 \times 10^{6}$ cells and $250 \mu \mathrm{g} \mathrm{MPP} / 0.1 \times 10^{6}$ cells. B Influence of PLA particles on cells incubated with $2.5 \mu \mathrm{g}$ MPP/ $0.1 \times 10^{6}$ cells and $250 \mu \mathrm{g}$

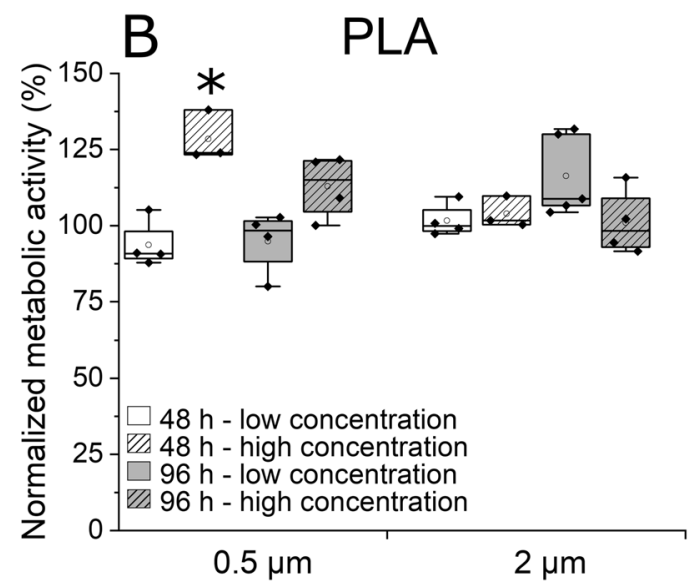

MPP/ $0.1 \times 10^{6}$ cells. Shown is the metabolic activity of cells normalized to a negative control (cells incubated without particles) analyzed using the MTT assay. $n \geq 3$. Statistically significant differences to the negative control are indicated by $*$ 


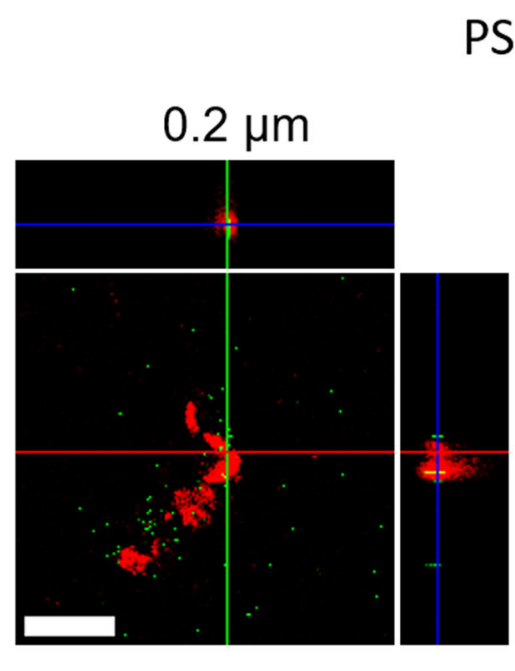

\section{PS}
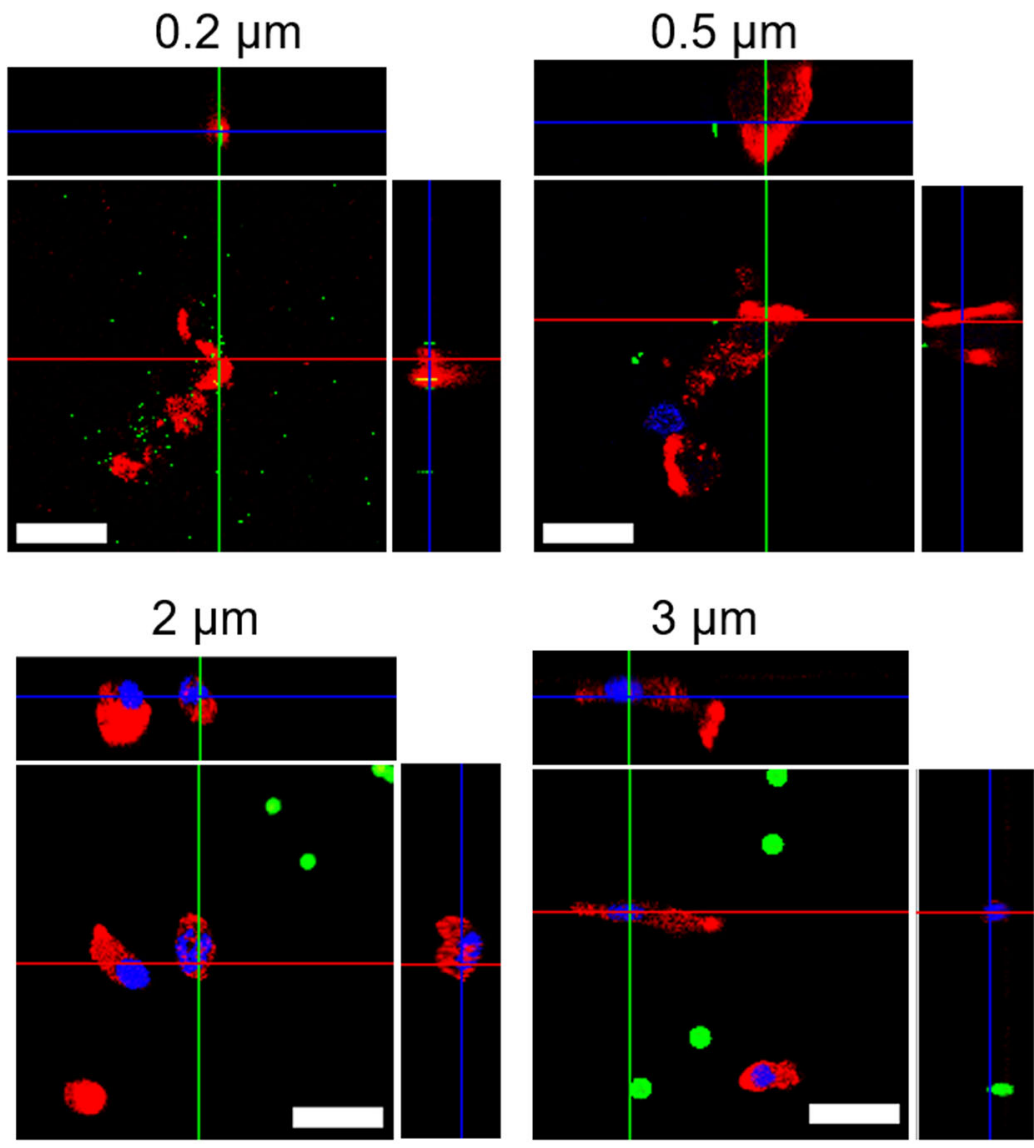

PLA
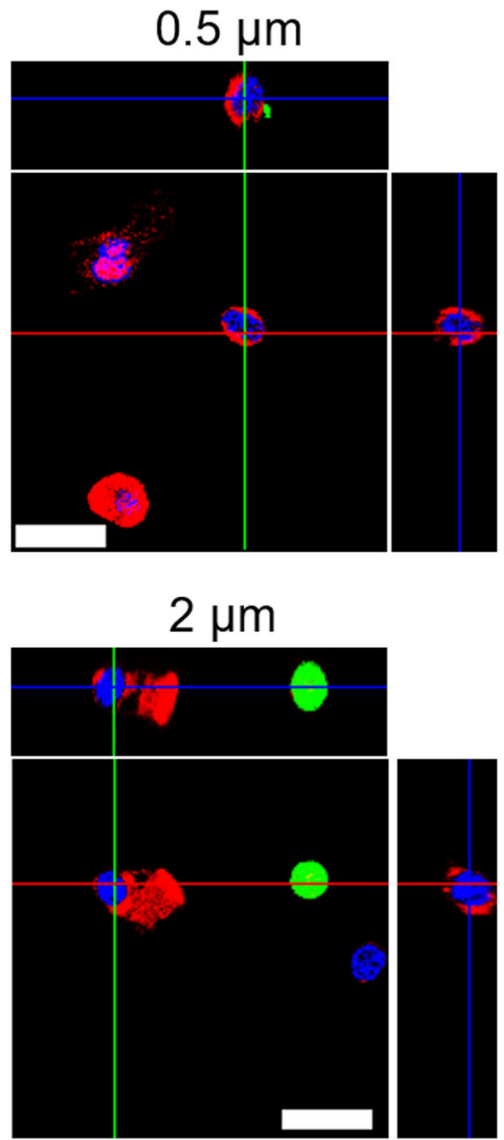

Fig. 7 Confocal laser scanning microscopy images of primary intestinal $E$. fetida cells incubated in presence of $2.5 \mu \mathrm{g} \mathrm{MPP} / 0.1 \times 10^{6}$ cells for $48 \mathrm{~h}$. The actin filaments were stained with rhodamine-phalloidin (red), nuclei were stained with DAPI (blue) and the FITC-fluorescent MP particles showed a green fluorescence. Scale bar $=20 \mu \mathrm{m}$ on the metabolic activity of the cells. Moreover, these findings are in line with recent results for murine epithelial cell lines, where also no uptake of particles $>0.2 \mu \mathrm{m}$ was observed (Rudolph et al. 2021). Particles with a size $<1 \mu \mathrm{m}$ already constitute nano/submicromaterials. The preference for their uptake by cells from various species stresses the need to extent the research on microplastic in the environment to that of nanoplastic (NP). In particular, it was show for a fish cell line that the synergistic effect of nanoparticles with environmental relevant metals like arsenic and methylmercury increases the cytotoxicity compared to the respective single effects (González-Fernández et al. 2021). Since the smallest investigated particles $(0.2 \mu \mathrm{m})$ seem to attach to cells, possible secondary or cumulative effects cannot be excluded. Organismic effects, like tissue damage or the inflammation of the gut tissue as shown previously (Jiang et al. 2020) might derive from particles which are not taken up by cells but persist in extracellular spaces in the tissue.

\section{Conclusion}

Establishing primary cells of model organisms for ecotoxicological studies is challenging, yet paves the way to mechanistic studies of the toxic effects on the cellular level. Here, we establish a method for the cultivation of primary intestinal cells of the earthworm E. fetida. Cells were kept viable and metabolically active for at least $144 \mathrm{~h}$. This is sufficient time to study cellular responses in detail, including in future also changes on the transcriptomic and metabolomic level. Utility for ecotoxicological tests on the cellular level was shown using known toxic agents. In contrast to the cytotoxic effects induced by these agents, MP particles neither induced any negative effects on the metabolic activity nor could active uptake of the particles be observed by the primary intestinal cells. In consequence, the established isolation method for intestinal primary cells from E. fetida allows more detailed studies on the cellular level to enhance our 
understanding how toxic effects of environmental pollutants are mediated on the organismic level.

Acknowledgements Darleen Lücker and Melanie Rothmaier supported this study by performing some preparations of the intestinal tract. Bettina Firmke, Anja Nicole Kretschmar, Lukas Jaegers and Peter Richter performed some isolations and subsequent cultivations or MTT assays. We thank the reviewers for their constructive and supporting suggestions. This work was funded by the Deutsche Forschungsgemeinschaft (DFG, German Research Foundation)—project number 391977956-SFB 1357 Mikroplastik/A02 and A05.

Author contributions SABR, MV, AH, VJ, TS, HF and RF designed the experiments and analyzed the data. AH maintained the earthworms and prepared the intestinal tracts. MV and SABR performed cultivation and ecotoxicity experiments. JJ provided the confocal microscopy and analysis of the pictures. SABR, MV, AH, JJ, VJ, TS, HF and RF wrote the manuscript. SABR, MV and AH created the figures. VJ, TS, $\mathrm{HF}$ and $\mathrm{RF}$ reviewed and edited the manuscript.

Funding This work was funded by the Deutsche Forschungsgemeinschaft (DFG, German Research Foundation)-project number 391977956-SFB 1357/A02 and A05. Open Access funding enabled and organized by Projekt DEAL.

\section{Compliance with ethical standards}

Conflict of interest The authors declare no competing interests.

Ethics approval The authors did not perform any experiments containing human participants, their data or biological material.

Publisher's note Springer Nature remains neutral with regard to jurisdictional claims in published maps and institutional affiliations.

Open Access This article is licensed under a Creative Commons Attribution 4.0 International License, which permits use, sharing, adaptation, distribution and reproduction in any medium or format, as long as you give appropriate credit to the original author(s) and the source, provide a link to the Creative Commons license, and indicate if changes were made. The images or other third party material in this article are included in the article's Creative Commons license, unless indicated otherwise in a credit line to the material. If material is not included in the article's Creative Commons license and your intended use is not permitted by statutory regulation or exceeds the permitted use, you will need to obtain permission directly from the copyright holder. To view a copy of this license, visit http://creativecommons. org/licenses/by/4.0/.

\section{References}

Battaglia M, Davoli C (1997) Long-term tissue culture of the earthworm Eisenia foetida (Annelida, Oligochaeta). In: Maramorosch K, Mitusuhashi J (eds) Invertebrate Cell Culture: Novel Directions and Biotechnology Applications. Science Publishers, Enfield, NH, USA, p 261-268

Bayley M, Overgaard J, Høj AS, Malmendal A, Nielsen NC, Holmstrup M, Wang T (2010) Metabolic Changes during Estivation in the Common Earthworm Aporrectodea caliginosa. Physiol Biochem Zool 83:541-550. https://doi.org/10.1086/651459

Bernard F, Brulle F, Dumez S, Lemiere S, Platel A, Nesslany F, Cuny D, Deram A, Vandenbulcke F (2015) Antioxidant responses of
Annelids, Brassicaceae and Fabaceae to pollutants: a review. Ecotoxicol Environ Saf 114:273-303. https://doi.org/10.1016/j. ecoenv.2014.04.024

Bilej M, Tuckova L, Rejnek J, Vetvicka V (1990) In vitro antigenbinding properties of coelomocytes of Eisenia foetida (Annelida). Immunol Lett 26:183-187. https://doi.org/10.1016/0165-2478 (90)90143-E

Büks F, Kaupenjohann M (2020) Global concentrations of microplastics in soils-a review. SOIL 6:649-662. https://doi.org/10. 5194/soil-6-649-2020

Chae Y, An Y-J (2018) Current research trends on plastic pollution and ecological impacts on the soil ecosystem: a review. Environ Pollut 240:387-395. https://doi.org/10.1016/j.envpol.2018.05. 008

Chen Y, Liu X, Leng Y, Wang J (2020) Defense responses in earthworms (Eisenia fetida) exposed to low-density polyethylene microplastics in soils. Ecotoxicol Environ Saf 187:109788. https://doi.org/10.1016/j.ecoenv.2019.109788

Davidenko N, Schuster CF, Bax DV, Farndale RW, Hamaia S, Best SM, Cameron RE (2016) Evaluation of cell binding to collagen and gelatin: a study of the effect of 2D and 3D architecture and surface chemistry. J Mater Sci Mater Med 27:148. https://doi.org/ 10.1007/s10856-016-5763-9

Dinno A (2017) dunn.test: Dunn's test of multiple comparisons using rank sums: Package "dunn.test”. Dinno. https://CRAN.R-project. org/package $=$ dunn.test

Diogène J, Dufour M, Poirier GG, Nadeau D (1997) Extrusion of earthworm coelomocytes: comparison of the cell populations recovered from the species Lumbricus terrestris, Eisenia fetida and Octolasion tyrtaeum. Lab Anim 31:326-336. https://doi.org/ 10.1258/002367797780596068

Engelmann P, Kiss J, Csöngei V, Cooper EL, Németh P (2004) Earthworm leukocytes kill HeLa, HEp-2, PC-12 and PA317 cells in vitro. J Biochem Biophys Methods 61:215-227. https://doi. org/10.1016/j.jbbm.2004.04.004

Eyambe GS, Goven AJ, Fitzpatrick LC, Venables BJ, Cooper EL (1991) A non-invasive technique for sequential collection of earthworm (Lumbricus terrestris) leukocytes during subchronic immunotoxicity studies. Lab Anim 25:61-67. https://doi.org/10. 1258/002367791780808095

Fuller-Espie SL, Harris DR, Daly JH, Jakeman JM (2015) Optimization of cell culture conditions for the earthworm Eisenia hortensis: a study investigating the effects of media, carbon dioxide, temperature, serum, and anti-fungal agents. J Pa Acad Sci 89:57-68

Garcia-Velasco N, Gandariasbeitia M, Irizar A, Soto M (2016) Uptake route and resulting toxicity of silver nanoparticles in Eisenia fetida earthworm exposed through Standard OECD Tests. Ecotoxicology 25:1543-1555. https://doi.org/10.1007/s10646-0161710-2

Garcia-Velasco N, Irizar A, Urionabarrenetxea E, Scott-Fordsmand JJ, Soto M (2019) Selection of an optimal culture medium and the most responsive viability assay to assess AgNPs toxicity with primary cultures of Eisenia fetida coelomocytes. Ecotoxicol Environ Saf 183:109545. https://doi.org/10.1016/j.ecoenv.2019.109545

Gong L, Lin X, Lu R, Yu L, Hou X, Li W (2014) Establishment of an in vitro culture system for intestinal epithelial cells from Pheretima aspergillum (E. Perrier). In Vitro Cell Dev Biol Anim 50:16-21. https://doi.org/10.1007/s11626-013-9679-0

González-Fernández C, Díaz Baños FG, Esteban MÁ, Cuesta A (2021) Functionalized nanoplastics (NPs) increase the toxicity of metals in fish cell lines. IJMS 22:7141. https://doi.org/10.3390/ijms22137141

Harnett EM, Alderman J, Wood T (2007) The surface energy of various biomaterials coated with adhesion molecules used in cell culture. Colloids Surf B Biointerfaces 55:90-97. https://doi.org/ 10.1016/j.colsurfb.2006.11.021 
He D, Bristow K, Filipović V, Lv J, He H (2020) Microplastics in terrestrial ecosystems: a scientometric analysis. Sustainability 12:8739. https://doi.org/10.3390/su12208739

Hothorn T, Bretz F, Westfall P (2008) Simultaneous inference in general parametric models. Biom J 50:346-363. https://doi.org/ 10.1002/bimj.200810425

Irizar A, Duarte D, Guilhermino L, Marigómez I, Soto M (2014) Optimization of NRU assay in primary cultures of Eisenia fetida for metal toxicity assessment. Ecotoxicology 23:1326-1335. https://doi.org/10.1007/s10646-014-1275-x

Irizar A, Rivas C, García-Velasco N, Goñi de Cerio F, Etxebarria J, Marigómez I, Soto M (2015) Establishment of toxicity thresholds in subpopulations of coelomocytes (amoebocytes vs. eleocytes) of Eisenia fetida exposed in vitro to a variety of metals: implications for biomarker measurements. Ecotoxicology 24:1004-1013. https://doi.org/10.1007/s10646-015-1441-9

Jiang X, Chang Y, Zhang T, Qiao Y, Klobučar G, Li M (2020) Toxicological effects of polystyrene microplastics on earthworm (Eisenia fetida). Environ Pollut 259:113896. https://doi.org/10. 1016/j.envpol.2019.113896

Kwak JI, Lee W-M, Kim SW, An Y-J (2014) Interaction of citratecoated silver nanoparticles with earthworm coelomic fluid and related cytotoxicity in Eisenia andrei. J Appl Toxicol 34:1145-1154. https://doi.org/10.1002/jat.2993

Leibovitz A (1963) The growth and maintenance of tissue-cell cultures in free gas exchange with the atmosphere. Am J Hyg 78:173-180. https://doi.org/10.1093/oxfordjournals.aje.a120336

Liberio MS, Sadowski MC, Soekmadji C, Davis RA, Nelson CC (2014) Differential effects of tissue culture coating substrates on prostate cancer cell adherence, morphology and behavior. PLoS ONE 9:e112122. https://doi.org/10.1371/journal.pone.0112122

Miles HB (1963) Heat-death temperature in Allolobophora terrestris (Sav.) forma longa (Ude) and Eisenia foetida (Sav.). Nature 199:826. https://doi.org/10.1038/199826a0

Nahmani J, Hodson ME, Black S (2007) A review of studies performed to assess metal uptake by earthworms. Environ Pollut 145:402-424. https://doi.org/10.1016/j.envpol.2006.04.009

Neuhauser EF, Loehr RC, Milligan DL, Malecki MR (1985) Toxicity of metals to the earthworm Eisenia fetida. Biol Fert Soils 1:149-152. https://doi.org/10.1007/BF00301782

Pass DA, Morgan AJ, Read DS, Field D, Weightman AJ, Kille P (2015) The effect of anthropogenic arsenic contamination on the earthworm microbiome. Environ Microbiol 17:1884-1896. https://doi.org/10.1111/1462-2920.12712

Piehl S, Leibner A, Löder MGJ, Dris R, Bogner C, Laforsch C (2018) Identification and quantification of macro- and microplastics on an agricultural farmland. Sci Rep 8:17950. https://doi.org/10. 1038/s41598-018-36172-y

Presley ML, McElroy TC, Diehl WJ (1996) Soil moisture and temperature interact to affect growth, survivorship, fecundity, and fitness in the earthworm Eisenia fetida. Comp Biochem Physiol 114:319-326. https://doi.org/10.1016/0300-9629(96)00017-5

R Core Team (2020) R: A language and environment for statistical computing. R Foundation for Statistical Computing, Vienna, Austria, http://www.r-project.org/index.html

Rahman MA (2019) Collagen of Extracellular Matrix from Marine Invertebrates and Its Medical Applications. Mar Drugs 17:118. https://doi.org/10.3390/md17020118

Ramsperger AFRM, Narayana VKB, Gross W, Mohanraj J, Thelakkat M, Greiner A, Schmalz H, Kress H, Laforsch C (2020)
Environmental exposure enhances the internalization of microplastic particles into cells. Sci Adv 6:eabd1211. https://doi.org/ 10.1126/sciadv.abd1211

Revel M, Roman C, Châtel A (2021) Is cell culture a suitable tool for the evaluation of micro- and nanoplastics ecotoxicity? Ecotoxicology 30:421-430. https://doi.org/10.1007/s10646-021-02355-z

Ricard-Blum S (2011) The Collagen Family. Cold Spring Harb Perspect Biol 3:a004978. https://doi.org/10.1101/cshperspect.a004978

Roch P, Valembios P, Du Pasquier L (1975) Response of Earthworm Leukocytes to Concanavalin a and Transplantation Antigens. In: Hildemann WH, Benedict AA (eds.) Immunologic Phylogeny: Advances in Experimental Medicine and Biology, vol 64. Springer, Boston, MA, USA, p 45-54

Rodriguez-Seijo A, Lourenço J, Rocha-Santos TAP, Da Costa J, Duarte AC, Vala H, Pereira R (2017) Histopathological and molecular effects of microplastics in Eisenia andrei Bouché. Environ Pollut 220:495-503. https://doi.org/10.1016/j.envpol. 2016.09.092

Rodríguez-Seijo A, da Costa JP, Rocha-Santos T, Duarte AC, Pereira $\mathrm{R}$ (2018) Oxidative stress, energy metabolism and molecular responses of earthworms (Eisenia fetida) exposed to low-density polyethylene microplastics. Environ Sci Pollut Res Int 25:33599-33610. https://doi.org/10.1007/s11356-018-3317-z

Rudolph J, Völkl M, Jérôme V, Scheibel T, Freitag R (2021) Noxic effects of polystyrene microparticles on murine macrophages and epithelial cells. Sci Rep 11:1-16. https://doi.org/10.1038/s41598021-95073-9

Shoults-Wilson WA, Reinsch BC, Tsyusko OV, Bertsch PM, Lowry GV, Unrine JM (2011) Effect of silver nanoparticle surface coating on bioaccumulation and reproductive toxicity in earthworms (Eisenia fetida). Nanotoxicology 5:432-444. https://doi. org/10.3109/17435390.2010.537382

Sivakumar S (2015) Effects of metals on earthworm life cycles: a review. Environ Monit Assess 187:530. https://doi.org/10.1007/ s10661-015-4742-9

von Smoluchowski M (1906) Zur kinetischen Theorie der Brownschen Molekularbewegung und der Suspensionen. Ann. Phys. 326:756-780. https://doi.org/10.1002/andp.19063261405

Stankiewicz A, Plytycz B (1998) Effects of in vitro conditions and in vivo thermal adaptation on viability of the earthworm (Eisenia fetida) coelomocytes. Folia Biologica 46:183-188

Stein E, Cooper EL (1981) The role of Opsonins in phagocytosis by coelomocytes of the earthworm, Lumbricus Terrestris. Dev Comp Immunol 5:415-425. https://doi.org/10.1016/S0145305X(81)80054-7

Toupin J, Marks DH, Cooper EL, Lamoureux G (1977) Earthworm coelomocytes in vitro. In Vitro 13:218-222. https://doi.org/10. 1007/bf02615078

Tripathi G, Bhardwaj P (2004) Comparative studies on biomass production, life cycles and composting efficiency of Eisenia fetida (Savigny) and Lampito mauritii (Kinberg). Bioresour Technol 92:275-283. https://doi.org/10.1016/j.biortech.2003.09.005

Wang J, Coffin S, Sun C, Schlenk D, Gan J (2019) Negligible effects of microplastics on animal fitness and HOC bioaccumulation in earthworm Eisenia fetida in soil. Environ Pollut 249:776-784. https://doi.org/10.1016/j.envpol.2019.03.102

Weithmann N, Möller JN, Löder MGJ, Piehl S, Laforsch C, Freitag R (2018) Organic fertilizer as a vehicle for the entry of microplastic into the environment. Sci Adv 4:eaap8060. https://doi.org/10. 1126/sciadv.aap8060 